\title{
Diesel Exhaust Particle-Induced Cell Death of Cultured Normal Human Bronchial Epithelial Cells
}

\author{
Mitsuyoshi Matsuo, ${ }^{a}$ Toshio Shimada,,${ }^{a}$ Rie Uenishi, ${ }^{a}$ Naoko Sasaki,,${ }^{a}$ and Masaru SAGai ${ }^{b}$ \\ ${ }^{a}$ Department of Biology, Faculty of Science and High Technology Research Center, Konan University; 8-9-1 Okamoto, \\ Higashinada-ku, Kobe, Hyogo 658-8501, Japan: ${ }^{b}$ Division of Nursing and Human Sciences, Faculty of Health Sciences, \\ Aomori University of Health and Welfare; 58-1 Aza Mase, Oaza Hamadate, Aomori, Aomori 030-8505, Japan. \\ Received October 15, 2002; accepted January 11, 2003
}

\begin{abstract}
We investigated the effect of diesel exhaust particles (DEPs) on normal human bronchial epithelial (NHBE) cells. Inclusion of DEPs in culture media was lethal to NHBE cells. NHBE cells are more susceptible to DEPs than other normal human lung cells, normal human pulmonary artery endothelial cells and normal human embryonic lung fibroblasts. DEP-induced cell death was mainly due to necrosis. Using the fluorescence probes diacetoxymethyl 6-carboxy-3', $6^{\prime}$-diacetoxy-2', $7^{\prime}$-dichloro-3', $6^{\prime}$-dideoxydihydrofluorescinate and 4,5-diaminofluorescein diacetate, it was observed that hydrogen peroxide and nitrogen monoxide, respectively, were generated within DEP-exposed NHBE cells. DEP cytotoxicity increased or decreased with an increase or decrease in the cellular level of reduced glutathione (GSH) by treatment with L-buthionine- $(R, S)$-sulfoximine or ethyl reduced glutathionate, respectively. In addition, DEPs themselves decreased the cellular level of GSH in a dose-dependent manner. Upon exposure of NHBE cells to high concentrations of DEPs, their cellular GSH was depleted almost throughout. Further, the following agents decreased DEP cytotoxicity: 1) antioxidants 2,2,5,7,8-pentamethylchroman-6-ol, ebselen, and $N, N^{\prime}$-bis(salicylidene)ethylenediaminomanganese(II) dihydrate (EUK-8); 2) iron ionchelating agents disodium bathophenanthrolinedisulfonate and desferrioxamine mesylate; 3) nitrogen monoxide synthase inhibitors $N^{\mathrm{G}}$-nitro-L-arginine methyl ester hydrochloride and $N^{\mathrm{G}}$-methyl-L-arginine acetate salt; and 4) an endocytosis inhibitor quinacrine. On the basis of these observations, the mechanism of DEP cytotoxicity toward NHBE cells is discussed.
\end{abstract}

Key words bronchial epithelial cell; diesel exhaust particle; necrosis; reactive oxygen species; quinacrine; reduced glutathione

Air pollution from manufacturing industries has been much improved, but that from transport industries is still a serious problem. In transport industries, diesel engines are predominantly used in heavy-duty trucks, buses, locomotives, and ships because of their greater efficiency and lower cost compared with gasoline engines. However, much more nitrogen oxides and exhaust particles are emitted from the former than from the latter. Both nitrogen oxides and exhaust particles are very harmful to the human body, in particular respiratory organs. Recently, epidemiological studies have shown that increases in morbidity and mortality are associated with particulate air pollution of respirable size. Diesel exhaust particles (DEPs) are considered to be the causative agents of lung cancer and chronic obstructive pulmonary diseases. ${ }^{1-3)}$ It has been reported that DEPs induce tumors in the respiratory tract and chronic obstructive pulmonary diseases in animals, ${ }^{4,5)}$ and that a small amount instilled intratracheally result in death. ${ }^{6}$ ) Thus, it is of great importance to elucidate the biological and biochemical effects of DEPs.

Although the mechanisms underlying respiratory diseases due to DEPs are not clear, it is considered that DEPs can be breathed most deeply into the lung, where they may exert toxicity. It has been reported that DEPs generate the superoxide radical and hydroxyl radical in a buffered suspension ${ }^{6}$ ) and the superoxide radical in the presence of hydrogen peroxide and cysteine. ${ }^{7)}$ Intratracheal instillation of DEPs in mice caused death from lung edema, and the death rate was reduced by intravenous injection of polyethyleneglycol-conjugated superoxide dismutase (PEG-SOD). ${ }^{6)}$ Furthermore, repeated intratracheal instillation of DEPs in mice caused asthma-like symptoms and PEG-SOD attenuated these symptoms such as infiltration of inflammatory cells, proliferation of goblet cells, increased mucus secretion, respiratory resistance, and airway constriction. ${ }^{5}$ In addition, repeated intratracheal instillation of DEPs in mice doubled the level of nitrogen monoxide (nitric oxide: NO) in exhaled air, and DEP administration increased the level of constitutive nitrogen monoxide synthase in the airway epithelium and the level of inducible nitrogen monoxide synthase in macrophages. ${ }^{8)}$ Thus, DEPs are likely to act in vitro and in vivo as a reactive oxygen species-generating agent and hence to be toxic toward biological systems.

However, there are only a limited number of reports of studies on DEP cytotoxicity. We have already shown that DEPs are cytotoxic toward HL-60 cells and suggested that DEP cytotoxicity results from the generation of reactive oxygen species (ROS) due to DEPs that have been incorporated into cells. ${ }^{9)}$ Bai et al. observed that DEPs and DEP extracts with organic solvents were cytotoxic toward normal human pulmonary artery endothelial (NHPAE) cells and that the superoxide radical, hydrogen peroxide, and NO were involved in DEP cytotoxicity. ${ }^{10)}$ Hiura et al. reported that DEPs and DEP extracts with organic solvents induced apoptosis in macrophages. ${ }^{11)}$ Bayram et al. reported that DEPs and filtered DEP suspensions attenuated the ciliary beat frequency of bronchial epithelial cells and increased the release of cytokines, including interleukin-8, colony-stimulating factor, and soluble intercellular adhesion molecule-1, from cells. ${ }^{12)}$

DEPs are cytotoxic. In particular, DEP cytotoxicity toward NHPAE cells is implicated in pulmonary edema leading to lethal pulmonary dysfunction. ${ }^{10}$ ) On the other hand, normal human bronchial epithelial (NHBE) cells are directly exposed to DEPs in the air, because DEPs are breathed deeply into the lung. Thus, the cells may be the first target of DEP 
cytotoxicity inducing pulmonary damage. It is of great importance to clarify details of DEP cytotoxicity toward NHBE cells.

We investigated the effect of DEPs on NHBE cells and compared the susceptibility of NHBE cells to DEPs with those of other normal human lung cell types.

\section{MATERIALS AND METHODS}

Diesel Exhaust Particles DEPs were prepared at the National Institute for Environmental Studies (Tsukuba, Japan) as described previously. ${ }^{6}$ DEPs were collected on a glass fiber filter in a constant-volume sampler system attached to the end of stainless steel dilution tunnel. Particle size was adjusted to a mass median aerodynamic diameter of $0.4 \mu \mathrm{m}$. Residual DEPs were obtained as follows. Five grams of DEPs were extracted serially with hexane, benzene, dichloromethane, methanol, and finally, $1 \mathrm{~N}$ ammonium hydroxide; for each extraction, the DEPs were allowed to stand, with gentle stirring, in $100 \mathrm{ml}$ of each solvent at room temperature for $1 \mathrm{~h}$ and after removal of the solvent in another $100 \mathrm{ml}$ of the same solvent. The resulting DEPs were washed with water, dried in a desiccator, and used as residual DEPs.

Materials $N$-Acetyl-L-cysteine, L-buthionine- $(R, S)$-sulfoximine (BSO), quinacrine, DL- $\alpha$-tocopherol, trypan blue, and Tween 80 were purchased from Wako Pure Chemical Industries Co., Ltd. (Osaka, Japan), disodium bathophenanthrolinedisulfonate, disodium ethylenediaminetetraacetate (EDTA), 2-[4-(2-hydroxyethyl)-1-piperazinyl]ethanesulfonic acid (HEPES), and propidium iodide (PI) from Dojindo Laboratories (Mashikicho, Kumamoto, Japan), catalase, desferrioxamine mesylate, 2-phenyl-1,2-benzisoselenazol-3[2H]one (ebselen), ethyl reduced glutathionate (reduced glutathione ethyl ester: EGSH), reduced glutathione (GSH), $N^{\mathrm{G}}$ nitro-L-arginine methyl ester hydrochloride (N-NAME), $N^{\mathrm{G}}$ methyl-L-arginine acetate salt (L-NMA), and superoxide dismutase (SOD) from Sigma-Aldrich Co. (St. Louis, MO, U.S.A.), the annexin V-fluorescein isothiocyanate (FITC) apoptosis detection kit I from Becton Dickinson Biosciences (Palo Alto, CA, U.S.A.), N, $N^{\prime}$-bis(salicylidene)ethylenediaminomanganese(II) dihydrate (EUK-8) from CalbiochemNovabiochem Corporation (San Diego, CA, U.S.A.), the caspase 3 assay kit No. 1 and diacetoxymethyl 6-carboxy-3', $6^{\prime}$ diacetoxy-2', $7^{\prime}$-dichloro-3', 6' -dideoxydihydrofluorescinate (DF) from Molecular Probes, Inc. (Eugene, OR, U.S.A.), 4,5diaminofluorescein diacetate (DAF-2 DA) from Daiichi Pure Chemicals Co. Ltd. (Tokyo, Japan), Coomassie brilliant blue G-250 from Fluka AG (Buchs, Switzerland), trypsin from Difco Laboratory (Detroit, MI, U.S.A.), and ribonuclease (RNase) from Boehringer Mannheim GmbH (Mannheim, Germany). 2,2,5,7,8-Pentamethylchroman-6-ol (PMC) was synthesized as described previously. ${ }^{13)}$ A small airway epithelial cell growth medium (SAEGM) and endothelial cell growth medium (EGM-2) were obtained from BioWhittaker, Inc. (Walkerville, MD, U.S.A.). Eagle's minimum essential medium (MEM) and Dulbecco's modified MEM (DMEM) were purchased from Nissui Pharmaceutical Co., Ltd. (Tokyo, Japan), and fetal bovine serum (FBS) from Moregate Laboratories (Melbourne, Australia). Falcon 6-cm, 10-cm, and 24-well plastic plates, and 5-ml polystyrene round-bottomed tubes, each with a cell-strainer cap, were purchased from Becton Dickinson Labware (Lincoln Park, NJ, U.S.A.). Other chemicals and materials were obtained from ordinary commercial sources.

Cells and Cell Culture NHBE and NHPAE cells were obtained from BioWhittaker, Inc. and normal human lung embryonic fibroblasts TIG-1 and TIG-7 from the Tokyo Metropolitan Institute of Gerontology. ${ }^{14,15)}$ Cells were cultivated under a humidified atmosphere of 5\% carbon dioxide and $95 \%$ air at $37^{\circ} \mathrm{C}$. Cell counting was done using a Coulter counter (Model Z-1, Coulter Corporation, Hialeah, FL, U.S.A.). Cell viability was determined using the trypan blue dye-exclusion test. ${ }^{16)}$ Total protein was quantified using the Coomassie brilliant blue staining method. ${ }^{17)}$

NHBE cells were cultivated in 6-cm plates, each of which contained $4 \mathrm{ml}$ of SAEGM, unless otherwise noted, and subcultivated at subconfluency. Subcultivation was performed with an inoculum size of $4 \times 10^{3}$ cells $/ \mathrm{cm}^{2}$ with $0.025 \%$ trypsin and $0.01 \%$ EDTA in an HEPES-buffered solution at $\mathrm{pH} 7.4$, which was composed of $30 \mathrm{~mm}$ HEPES, $130 \mathrm{~mm}$ sodium chloride, $3 \mathrm{~mm}$ potassium chloride, $3 \mathrm{~mm}$ disodium hydrogenphosphate, $10 \mathrm{~mm}$ glucose, and $133 \mathrm{~mm}$ sodium hydroxide. Medium was changed every $2 \mathrm{~d}$. Cells were used at 5-9 population doubling levels (PDL).

NHPAE cells were cultivated in 6-cm plates, each of which contained $4 \mathrm{ml}$ of EGM-2, and subcultivated at subconfluency. Subcultivation was performed with an inoculum size of $4 \times 10^{3}$ cells $/ \mathrm{cm}^{2}$ with $0.025 \%$ trypsin and $0.01 \%$ EDTA in the HEPES-buffered solution. Medium was changed every $2 \mathrm{~d}$. Cells were used at 4-10 PDL.

TIG cells were cultivated in 6-cm plates, each of which contained $4 \mathrm{ml}$ of $10 \%$ FBS-supplemented MEM. Subcultivation was performed weekly at a $4: 1$ splitting ratio with $0.25 \%$ trypsin in calcium- and magnesium-free phosphatebuffered saline at $\mathrm{pH} 7.4$ (PBS). Medium was changed $3 \mathrm{~d}$ after subcultivation. Cells were used at 13-17 PDL.

Exposure of Cells to Diesel Exhaust Particles A suspension of $2 \mathrm{mg} / \mathrm{ml}$ DEPs was prepared by sonication of $10 \mathrm{mg}$ of DEPs in $5 \mathrm{ml}$ of $0.0025 \%$ Tween 80 -containing Earle's solution at 50 watts for 2 min using a sonicator (Model 250 Sonifier, Branson Ultrasonic Corporation, Danbury, CT, U.S.A.). The DEP suspension was diluted in Earle's solution to appropriate concentrations. For the experiments, Earle's solution was chosen as a relatively simple buffered saline without organic compounds except for glucose.

NHBE cells were inoculated at a density of $5 \times 10^{4}$ cells $/ \mathrm{cm}^{2}$ in 24-well plates, each well of which contained $0.5 \mathrm{ml}$ of SAEGM, and cultivated overnight. After removal of the medium, the cells in each well were washed with $0.5 \mathrm{ml}$ of Earle's solution. To the cells, $0.5 \mathrm{ml}$ of the DEP suspension at an appropriate concentration was added. The cells were incubated at $37^{\circ} \mathrm{C}$ for $1 \mathrm{~h}$. Substrate-detached cells in the suspension were transferred into a $1.5-\mathrm{ml}$ sampling tube. The detached cells were pelleted by centrifugation. On the other hand, the substrate-adherent cells were washed with $1 \mathrm{ml}$ of Earle's solution and incubated with $0.1 \mathrm{ml}$ of $0.0025 \%$ trypsin at $37^{\circ} \mathrm{C}$ for $5 \mathrm{~min}$. To the cells, $0.1 \mathrm{ml}$ of the $0.5 \%$ FBS-supplemented HEPES-buffered solution was added. The cells were pipetted and transferred into the 1.5$\mathrm{ml}$ sampling tube containing the detached cells. After centrifugation and removal of the supernatant, their percent survival was determined. 
For comparison of DEP susceptibility between different cell types, NHBE cells, NHPAE cells, or TIG cells were inoculated at a density of $3 \times 10^{3} \mathrm{cells} / \mathrm{cm}^{2}$ in 24 -well plates, each well of which contained $0.5 \mathrm{ml}$ of SAEGM, EGM-2, or $10 \%$ FBS-supplemented MEM, respectively, and cultivated overnight. After removal of each medium, the cells were washed with 1\% FBS- and $20 \mathrm{mM}$-HEPES-supplemented DMEM, and incubated for $1 \mathrm{~h}$ in the DMEM containing DEPs at an appropriate concentration. After centrifugation and removal of the medium, the cells were washed with $0.5 \mathrm{ml}$ of Earle's solution. Their percent survival was determined.

Microscopy Observations and photographs were made using an Olympus IX70 inverted microscope equipped with an Olympus IX-FLA epifluorescence attachment and an Olympus DP-50 digital camera (Olympus Optical Co., Ltd., Tokyo, Japan). For detection of intracellularly generated ROS, DF- or DAF-2-preincubated cells were exposed to DEPs and then visualized under illumination at $470-490 \mathrm{~nm}$.

Flow Cytometry Flow cytometric analysis was performed using a BD LSR flow cytometer equipped with a single 488-nm argon laser (Becton Dickinson Biosciences, San Jose, CA, U.S.A.).

Observation of Apoptosis NHBE cells were inoculated at a density of $2 \times 10^{5}$ cells $/ \mathrm{cm}^{2}$ in 6-cm plates, each of which contained $4 \mathrm{ml}$ of SAEGM, and cultivated overnight. After removal of the medium, the cells in each plate were incubated with $4 \mathrm{ml}$ of the DEP suspension at an appropriate concentration in Earle's solution at $37^{\circ} \mathrm{C}$ for $1 \mathrm{~h}$. After removal of the supernatant, the cells were washed with $4 \mathrm{ml}$ of Earle's solution. After removal of the solution, $1 \mathrm{ml}$ of $0.025 \%$ trypsin and $0.01 \%$ EDTA in the HEPES-buffered solution was added to the cells and then aspirated off. The cells were incubated at $37^{\circ} \mathrm{C}$ for $5 \mathrm{~min}$. To the cells, $1 \mathrm{ml}$ of the $0.5 \%$ FBS-supplemented HEPES-buffered solution and $3 \mathrm{ml}$ of Earle's solution were added. The cells were suspended in a centrifuge tube and centrifuged. A cell pellet was obtained.

Annexin V-Fluorescein Isothiocyanate Staining: After being washed twice with PBS, the cells were suspended at a density of $1 \times 10^{6}$ cells $/ \mathrm{ml}$ in a binding buffer, which was composed of $10 \mathrm{~mm}$ HEPES, $140 \mathrm{~mm}$ sodium chloride, and $2.5 \mathrm{~mm}$ calcium chloride at $\mathrm{pH}$ 7.4. In a 5-ml polystyrene round-bottomed tube, $0.1 \mathrm{ml}$ of the cell suspension was mixed with $5 \mu \mathrm{l}$ of the annexin V-FITC solution, a component of the apoptosis detection kit, and $50 \mu \mathrm{g} / \mathrm{ml}$ PI in PBS using a Vortex mixer. The cell suspension was allowed to stand in the dark at room temperature for $15 \mathrm{~min}$, and $0.4 \mathrm{ml}$ of the binding buffer was added. Using two-color flow cytometry, the fluorescence intensity of annexin V-FITC was analyzed at an excitation wavelength of $488 \mathrm{~nm}$ and emission wavelength of $530 \mathrm{~nm}$, and that of PI was analyzed at an excitation wavelength of $488 \mathrm{~nm}$ and emission wavelength of $617 \mathrm{~nm}$.

Propidium Iodide Staining: The cells were suspended at a density of $1 \times 10^{6}$ cells $/ \mathrm{ml}$ in $0.5 \mathrm{ml}$ of PBS and transferred into a centrifuge microtube. After centrifugation, the cell pellet obtained was mixed with $0.3 \mathrm{ml}$ of PBS and $0.7 \mathrm{ml}$ of ethanol and allowed to stand at $4{ }^{\circ} \mathrm{C}$ for $30 \mathrm{~min}$. After centrifugation, the pellet was mixed with $0.5 \mathrm{ml}$ of PBS containing $2 \mathrm{mg} / \mathrm{ml} \mathrm{RNase}$ and incubated at $37^{\circ} \mathrm{C}$ for $30 \mathrm{~min}$. After centrifugation, the pellet was mixed with $90 \mu \mathrm{l}$ of PBS and
$10 \mu \mathrm{l}$ of $2 \mathrm{mg} / \mathrm{ml} \mathrm{PI}$ and allowed to stand in the dark at room temperature for $20 \mathrm{~min}$. After the addition of $0.9 \mathrm{ml}$ of the binding buffer, the PI-stained cells with hypodiploid DNA were observed by flow cytometry at an excitation wavelength of $488 \mathrm{~nm}$ and emission wavelength of $617 \mathrm{~nm}$.

Caspase 3 Activity Assay: Caspase 3 activity was assayed using the caspase 3 assay kit. Briefly, $1 \times 10^{6}$ cells were washed with $0.5 \mathrm{ml}$ of PBS in a centrifuge microtube and suspended in $50 \mu \mathrm{l}$ of the cell lysis buffer, a component of the caspase 3 assay kit. The cells were allowed to stand on ice for $30 \mathrm{~min}$. After centrifugation at $5000 \mathrm{rpm}$ for $5 \mathrm{~min}$, the supernatant was mixed with $50 \mu 1$ of $10 \mathrm{~mm}$ Z-DEVD-7amino-4-methylcoumarin in a mixture of $10 \mathrm{~mm}$ PIPES, $0.2 \%$ CHAPS, and $2 \mathrm{~mm}$ EDTA. The mixture was incubated at room temperature for $30 \mathrm{~min}$ and diluted five times with PBS. Its fluorescence intensity was determined at an excitation wavelength of $360 \mathrm{~nm}$ and emission wavelength of $430 \mathrm{~nm}$ using a Hitachi F2000 fluorescence spectrophotometer (Hitachi, Ltd., Tokyo, Japan).

Quantification of Intracellularly Generated Reactive Oxygen Species in Normal Human Bronchial Epithelial Cells DF was solubilized in ethanol at a concentration of $7.4 \mathrm{~mm}$ and diluted in Earle's solution to $5 \mu \mathrm{M} .{ }^{17)}$ Cells were inoculated at a density of $2 \times 10^{4}$ cells $/ \mathrm{cm}^{2}$ in $6-\mathrm{cm}$ plates, each of which contained $4 \mathrm{ml}$ of SAEGM, and cultivated overnight. After removal of the medium, the cells in each plate were washed with $1 \mathrm{ml}$ of Earle's solution and incubated in $4 \mathrm{ml}$ of $5 \mu \mathrm{M}$ DF in Earle's solution at $37^{\circ} \mathrm{C}$ for $30 \mathrm{~min}$. After removal of the solution, the cells were exposed to $2 \mathrm{ml}$ of the DEP suspension at an appropriate concentration at $37^{\circ} \mathrm{C}$ for $1 \mathrm{~h}$. After removal of the suspension, the cells were incubated with $0.1 \%$ trypsin for $5 \mathrm{~min}$. To the cells, $0.1 \mathrm{ml}$ of the $0.5 \%$ FBS-supplemented HEPES-buffered solution was added. The cells were pipetted and transferred into a $1.5-\mathrm{ml}$ sampling tube. After centrifugation, the pellet was suspended in $1 \mathrm{ml}$ of Earle's solution, and transferred into a 5-ml polystyrene round-bottomed tube through its cell strainer. The fluorescence intensity of oxidized DF was analyzed by flow cytometry at an excitation wavelength of $488 \mathrm{~nm}$ and emission wavelength of $530 \mathrm{~nm}$.

Quantification of Intracellularly Generated Nitrogen Monoxide in Normal Human Bronchial Epithelial Cells DAF-2 DA was solubilized in Earle's solution at a concentration of $5 \mu \mathrm{m}$. Cells were inoculated at a density of $2 \times 10^{4}$ cells $/ \mathrm{cm}^{2}$ in $6-\mathrm{cm}$ plates, each of which contained $4 \mathrm{ml}$ of SAEGM, and cultivated overnight. After removal of the medium, the cells in each plate were washed with $1 \mathrm{ml}$ of Earle's solution and incubated in $4 \mathrm{ml}$ of $5 \mu \mathrm{M}$ DAF-2 DA in Earle's solution at $37^{\circ} \mathrm{C}$ for $30 \mathrm{~min}$. After removal of the solution, the cells were exposed to $2 \mathrm{ml}$ of the DEP suspension at an appropriate concentration at $37^{\circ} \mathrm{C}$ for $1 \mathrm{~h}$. After removal of the suspension, the cells were incubated with $0.1 \%$ trypsin for $5 \mathrm{~min}$. To the cells, $0.1 \mathrm{ml}$ of the $0.5 \%$ FBS-supplemented HEPES-buffered solution was added. The cells were pipetted and transferred into a $1.5-\mathrm{ml}$ sampling tube. After centrifugation, the cell pellet was suspended in $1 \mathrm{ml}$ of Earle's solution and transferred into a 5-ml polystyrene round-bottomed tube through its cell strainer. The fluorescence intensity of NO-reacted DAF-2 DA was analyzed by flow cytometry at an excitation wavelength of $488 \mathrm{~nm}$ and emission wavelength of $530 \mathrm{~nm}$. 
Administration of Diesel Exhaust Particle Cytotoxicitymodulating Agents to Normal Human Bronchial Epithelial Cells Superoxide Dismutase and/or Catalase: In Earle's solution, SOD and/or catalase were solubilized at concentrations of 1 and/or 0.8 unit/ $\mu$, respectively. Cells were inoculated at a density of $3 \times 10^{4}$ cells $/ \mathrm{cm}^{2}$ in 24 -well plates, each of which contained $0.5 \mathrm{ml}$ of SAEGM, and cultivated overnight. After removal of the medium, the cells in each well were washed with $1 \mathrm{ml}$ of Earle's solution. To the cells, $0.1 \mathrm{ml}$ of the SOD and/or catalase solution, $0.4 \mathrm{ml}$ of Earle's solution, and $0.5 \mathrm{ml}$ of the DEP suspension at an appropriate concentration were added, i.e., the final concentrations of SOD and catalase were 100 and $80 \mathrm{unit} / \mathrm{ml}$, respectively. The cells were incubated at $37^{\circ} \mathrm{C}$ for $1 \mathrm{~h}$.

$N, N^{\prime}$-Bis(salicylidene)ethylenediaminomanganese(II) Dihydrate: EUK- 8 was solubilized in SAEGM at $150 \mu$ m. Cells were inoculated at a density of $3 \times 10^{4} \mathrm{cells} / \mathrm{cm}^{2}$ in 24-well plates, each of which contained $0.5 \mathrm{ml}$ of SAEGM, and cultivated overnight. After removal of the medium, the cells in each well were preincubated with $0.5 \mathrm{ml}$ of the $150 \mu \mathrm{M}$ EUK8 -supplemented medium at $37^{\circ} \mathrm{C}$ for $1 \mathrm{~h}$. After removal of the medium, the cells were washed with $0.5 \mathrm{ml}$ of Earle's solution and exposed to DEPs as described above.

$\alpha$-Tocopherol and 2,2,5,7,8-Pentamethylchroman-6-ol: $\alpha$ Tocopherol or PMC was solubilized in ethanol at a concentration of $50 \mathrm{~mm}$ and then diluted in SAEGM to $100 \mu \mathrm{M}$. Cells were inoculated at a density of $3 \times 10^{4}$ cells $/ \mathrm{cm}^{2}$ in $24-$ well plates, each of which contained $0.5 \mathrm{ml}$ of SAEGM, and cultivated overnight. After removal of the medium, the cells in each well were preincubated with $0.5 \mathrm{ml}$ of the $100 \mu \mathrm{M} \alpha$ tocopherol- or PMC-supplemented medium at $37^{\circ} \mathrm{C}$ for $24 \mathrm{~h}$. After removal of the medium, the cells were washed with $0.5 \mathrm{ml}$ of Earle's solution and exposed to DEPs as described above.

L-Buthionine- $(R, S)$-sulfoximine: BSO was solubilized in SAEGM at 10 or $20 \mu \mathrm{M}$. Cells were inoculated at a density of $3 \times 10^{4}$ cells $/ \mathrm{cm}^{2}$ in 24 -well plates, each of which contained $0.5 \mathrm{ml}$ of SAEGM, and cultivated overnight. After removal of the medium, the cells in each well were preincubated with $0.5 \mathrm{ml}$ of the 10 or $20 \mu \mathrm{M}$ BSO-supplemented medium at $37^{\circ} \mathrm{C}$ for $24 \mathrm{~h}$. After removal of the medium, the cells were washed with $0.5 \mathrm{ml}$ of Earle's solution and exposed to DEPs as described above.

Ethyl Reduced Glutathionate: EGSH was solubilized in SAEGM at 5 or $10 \mathrm{~mm}$. Cells were inoculated at a density of $3 \times 10^{4}$ cells $/ \mathrm{cm}^{2}$ in 24 -well plates, each of which contained $0.5 \mathrm{ml}$ of SAEGM, and cultivated overnight. After removal of the medium, the cells in each well were preincubated with $0.5 \mathrm{ml}$ of the 5 or $10 \mathrm{~mm}$ EGSH-supplemented medium at $37^{\circ} \mathrm{C}$ for $4 \mathrm{~h}$. After removal of the medium, the cells were washed with $0.5 \mathrm{ml}$ of Earle's solution and exposed to DEPs as described above.

Ebselen: Ebselen was solubilized in ethanol at $25 \mathrm{~mm}$ and then diluted in Earle's solution to $1 \mu \mathrm{M}$. Cells were inoculated at a density of $3 \times 10^{4}$ cells $/ \mathrm{cm}^{2}$ in 24-well plates, each of which contained $0.5 \mathrm{ml}$ of SAEGM, and cultivated overnight. After removal of the medium, the cells in each well were washed with $1 \mathrm{ml}$ of Earle's solution. The cells were incubated at $37^{\circ} \mathrm{C}$ for $1 \mathrm{~h}$ in a mixture of $0.5 \mathrm{ml}$ of the ebselen solution and $0.5 \mathrm{ml}$ of the DEP suspension at an appropriate concentration.
Desferrioxamine Mesylate and Disodium Bathophenanthrolinedisulfonate: Either $2 \mathrm{~mm}$ desferrioxamine mesylate or disodium bathophenanthrolinedisulfonate and $1 \mathrm{mg} / \mathrm{ml}$ DEPs were mixed in Earle's solution containing $0.0025 \%$ Tween 80 and sonicated at 50 watts for $2 \mathrm{~min}$. Immediately after the sonication, a half of the mixture was diluted with Earle's solution to appropriate concentrations and administered to cells. In addition, after being preincubated in the dark at $37^{\circ} \mathrm{C}$ for $24 \mathrm{~h}$, the other half of the mixture was diluted with Earle's solution to appropriate concentrations and administered to cells. Cells were inoculated at a density of $3 \times 10^{4}$ cells $/ \mathrm{cm}^{2}$ in 24-well plates, each of which contained $0.5 \mathrm{ml}$ of SAEGM, and cultivated overnight. After removal of the medium, the cells in each well were incubated at $37^{\circ} \mathrm{C}$ for $1 \mathrm{~h}$ with $0.5 \mathrm{ml}$ of each of the above mixtures containing DEPs at different concenrations.

$N^{\mathrm{G}}$-Nitro-L-arginine Methyl Ester Hydrochloride and $N^{\mathrm{G}}$ Methyl-L-arginine Acetate Salt: L-NAME or L-NMA was solubilized in SAEGM at $0.3 \mathrm{~mm}$. Cells were inoculated at a density of $3 \times 10^{4}$ cells $/ \mathrm{cm}^{2}$ in 24-well plates, each of which contained $0.5 \mathrm{ml}$ of SAEGM, and cultivated overnight. After removal of the medium, the cells in each well were preincubated at $37^{\circ} \mathrm{C}$ for $24 \mathrm{~h}$ in SAEGM containing $0.5 \mathrm{ml}$ of $0.3 \mathrm{~mm}$ L-NAME or L-NMA. After removal of the medium, the cells were washed with $0.5 \mathrm{ml}$ of Earle's solution and exposed to DEPs as described above.

Quinacrine: Quinacrine was solubilized in SAEGM at 0.2 or $0.4 \mathrm{~mm}$. Cells were inoculated at a density of $3 \times 10^{4}$ cells $/ \mathrm{cm}^{2}$ in 24-well plates, each of which contained $0.5 \mathrm{ml}$ of SAEGM, and cultivated overnight. After removal of the medium, the cells in each well were preincubated with $0.5 \mathrm{ml}$ of the 0.2 or $0.4 \mathrm{~mm}$ quinacrine-supplemented medium at $37^{\circ} \mathrm{C}$ for $15 \mathrm{~min}$. After removal of the medium, the cells were washed with $0.5 \mathrm{ml}$ of Earle's solution and exposed to DEPs as described above.

Determination of Reduced Glutathione Levels in Normal Human Bronchial Epithelial Cells L-Buthionine$(R, S)$-sulfoximine-Incubated Cells: Cells were inoculated at a density of $3 \times 10^{4}$ cells $/ \mathrm{cm}^{2}$ in $10-\mathrm{cm}$ plates, each of which contained $8 \mathrm{ml}$ of SAEGM, and cultivated overnight. After removal of the medium, the cells in each plate were washed with $8 \mathrm{ml}$ of the HEPES-buffered solution and incubated with $8 \mathrm{ml}$ of BSO solution at an appropriate concentration in SAEGM at $37^{\circ} \mathrm{C}$ for $24 \mathrm{~h}$.

Ethyl Reduced Glutathionate-Incubated Cells: As described above, cells were cultivated in $10-\mathrm{cm}$ plates overnight. After removal of the medium, the cells in each plate were washed with $8 \mathrm{ml}$ of the HEPES-buffered solution and incubated with $8 \mathrm{ml}$ of EGSH solution at an appropriate concentration in SAEGM at $37^{\circ} \mathrm{C}$ for $4 \mathrm{~h}$.

Diesel Exhaust Particle-Incubated Cells: As described above, cells were cultivated in $10-\mathrm{cm}$ plates overnight. After removal of the medium, $8 \mathrm{ml}$ of the DEP suspension at an appropriate concentration was added to the cells in each plate. The cells were incubated at $37^{\circ} \mathrm{C}$ for $1 \mathrm{~h}$.

Quantification of Reduced and Oxidized Glutathione: After removal of the medium, the BSO-, EGSH-, or DEP-incubated cells in each plate were washed with $8 \mathrm{ml}$ of the HEPES-buffered solution. The cells were incubated with $0.025 \%$ trypsin at $37^{\circ} \mathrm{C}$ for $3 \mathrm{~min}$. To the cells, $1.5 \mathrm{ml}$ of the $0.5 \%$ FBS-supplemented HEPES-buffered solution was 
added. The cells were transferred into a glass centrifuge tube and centrifuged. After removal of the supernatant, the cell pellet was resuspended in $3 \mathrm{ml}$ of $125 \mathrm{~mm}$ phosphate buffered saline containing $6.3 \mathrm{~mm}$ EDTA at $\mathrm{pH} 7.5$. To $0.8 \mathrm{ml}$ of the cell suspension, $0.2 \mathrm{ml}$ of $25 \%$ metaphosphoric acid was added. The cell suspension was sonicated at 20 watts for $10 \mathrm{~s}$ and centrifuged at $15000 \mathrm{rpm}$ for $15 \mathrm{~min}$. The supernatant obtained was neutralized to $\mathrm{pH} 7$ with $10 \mu \mathrm{l}$ of $10 \mathrm{M}$ sodium hydroxide. The levels of reduced and oxidized glutathione in it was quantified according to the method of Griffith. ${ }^{18)}$

Statistical Analysis Data are expressed as mean values and standard deviations. Differences in the mean values were assessed for significance by one-way analysis of variance (ANOVA) and the Scheffé F-test. $p$-Values of less than 0.05 were considered significant. Statistical analysis was performed using a Macintosh G3 computer (Apple Computer, Inc., Cupertino, CA, U.S.A.) with the Stat-View SE software program (Abacus Concepts, Inc., Berkeley, CA, U.S.A.).



Fig. 1. Survival Curves of Normal Human Bronchial Epithelial Cells Exposed to Diesel Exhaust Particles and Residual Diesel Exhaust Particles

Residual DEPs were obtained by serial extraction of DEPs with hexane, benzene, dichloromethane, methanol, and $1 \mathrm{~N}$ ammonium hydroxide. Cells were exposed to DEPs or residual DEPs at different concentrations at $37^{\circ} \mathrm{C}$ for $1 \mathrm{~h}$. Circles and squares show the percent survivals of DEP-exposed and residual DEP-exposed cells, respectively. Each symbol represents the mean value of three cell cultures, and the positive error bar represents the standard deviation. An asterisk means that the difference between a value of residual DEP-exposed cells and the corresponding value of DEP-exposed cells is statistically significant $(p<0.05)$.

\section{RESULTS}

Diesel Exhaust Particle Cytotoxicity toward Normal Human Bronchial Epithelial Cells Inclusion of DEPs in culture media was highly toxic toward NHBE cells; on DEP exposure for $1 \mathrm{~h}$, the 50 percent lethal concentration $\left(\mathrm{LC}_{50}\right)$ of DEPs was $140 \pm 4 \mu \mathrm{g} / \mathrm{ml}$ and all cells died in $500 \mu \mathrm{g} / \mathrm{ml}$ DEPs (Fig. 1). Most toxic materials in DEPs could not be extracted with organic solvents. About $80 \%$ of the cytotoxicity at $500 \mu \mathrm{g} / \mathrm{ml}$ DEPs was found in the residual DEPs obtained by a serial extraction of DEPs with hexane, benzene, dichloromethane, methanol, and $1 \mathrm{~N}$ ammonium hydroxide (Fig. 1).

DEP exposure led mainly to necrosis, not apoptosis. Flow cytometry revealed that when NHBE cells were exposed to 25 or $100 \mu \mathrm{g} / \mathrm{ml}$ DEPs for $1 \mathrm{~h}$, almost no hypodiploid DNA in the PI-stained cells (data not shown) and no increase in the annexin V-FITC-stained cells occurred (Fig. 2). In addition, the assay of caspase 3 activity revealed that in DEP-exposed NHBE cells, there was no increase in caspase 3 activity (data not shown).

Comparison of Diesel Exhaust Particle Susceptibility of Different Normal Human Lung Cell Types The DEP susceptibilities of NHBE cells, NHPAE cells, and normal human lung embryonic fibroblasts (TIG cells) were compared. As shown in Table 1, the order of $\mathrm{LC}_{50}$ values of these cell types was as follows: NHBE cells $<$ NHPAE cells $\ll$ TIG cells. The susceptibility of NHBE cells was higher than those of NHPAE cells and TIG cells.

Diesel Exhaust Particle-Induced Generation of Reactive Oxygen Species in Normal Human Bronchial Epithelial Cells Generation of Hydrogen Peroxide and Related Reactive Oxygen Species: When preincubated with the fluorescence probe DF and then exposed to DEPs, cells emitted green fluorescence under blue illumination (data not shown). The fluorescence shows that hydrogen peroxide and related ROS are generated within cells. Flow cytometry revealed that DEPs increased the intensity of DF fluorescence within cells in a dose-dependent manner (Fig. 3).

Generation of Nitrogen Monoxide: When preincubated
A

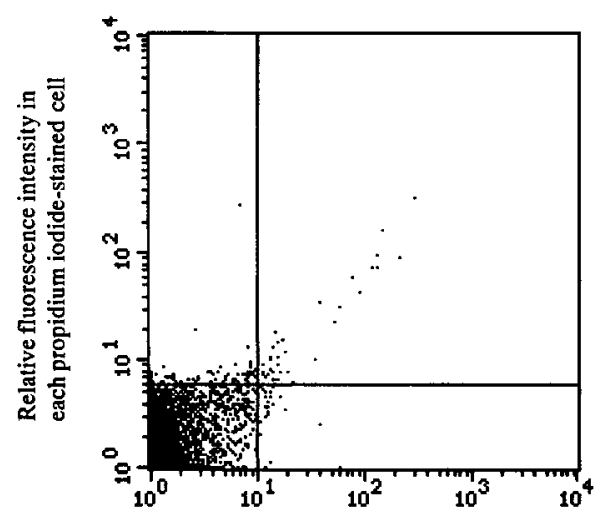

B

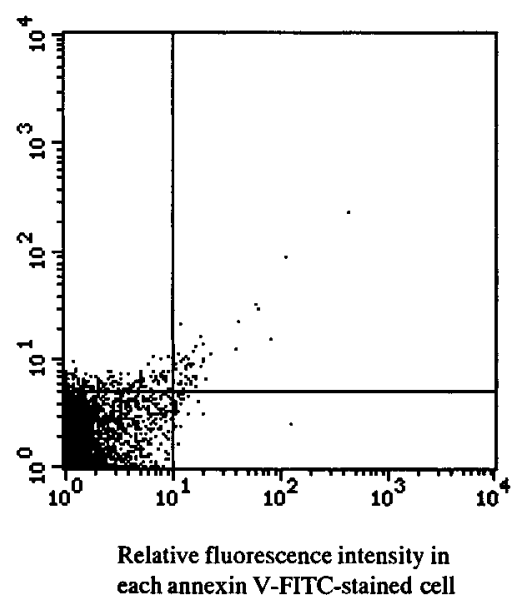

$\mathrm{C}$

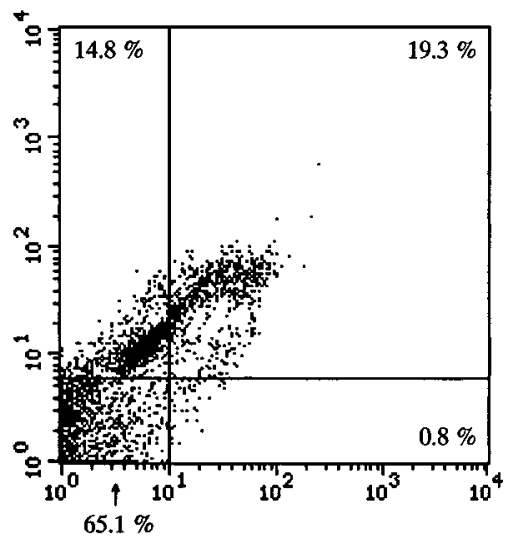

Fig. 2. Flow Cytometric Analysis of Diesel Exhaust Particle-Exposed Normal Human Bronchial Epithelial Cells by the Double Staining of Annexin V-Fluorescein Isothiocyanate and Propidium Iodide

The control (A), $25 \mu \mathrm{g} / \mathrm{ml}$ DEP-exposed (B), and $100 \mu \mathrm{g} / \mathrm{ml}$ DEP-exposed cells (C) were stained with a mixture of annexin V-FITC and PI. The fluorescence intensity of annexin V-FITC and PI was analyzed by two-color flow cytometry (see Materials and Methods). The numbers in each quadrant show the percentage of cells in it in a cell population. 
Table 1. Fifty Percent Lethal Concentration Values for DEPs in Different Normal Human Lung Cell Types

\begin{tabular}{lc}
\hline \hline \multicolumn{1}{c}{ Cell type } & LC $_{50}$ of DEPs $(\mu \mathrm{g} / \mathrm{ml})$ \\
\hline Bronchial epithelial cells & Mean $118 \pm 13^{*}$ \\
NHBE-8507 & 114,138 \\
NHBE-8934 & 109,114 \\
Pulmonary artery endothelial cells & Mean $137 \pm 6^{*}$ \\
NHPAE-2372 & 138,141 \\
NHPAE-8703 & 127,140 \\
Lung fibroblasts & Mean $270 \pm 18^{*}$ \\
TIG-1 & 282,242 \\
TIG-7 & 257,246 \\
\hline
\end{tabular}

The difference between any two asterisked values is statistically significant $(p<0.05)$.

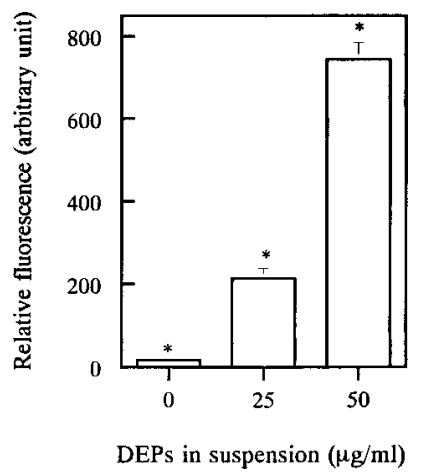

Fig. 3. Quantification of Reactive Oxygen Species Generated within Diesel Exhaust Particle-Exposed Normal Human Bronchial Epithelial Cells

Cells were incubated with $5 \mu \mathrm{M}$ DF in Earle's solution at $37^{\circ} \mathrm{C}$ for $30 \mathrm{~min}$ and then exposed to DEPs at different concentrations at $37^{\circ} \mathrm{C}$ for $1 \mathrm{~h}$. The fluorescence intensity of oxidized DF was analyzed by flow cytometry (see Materials and Methods). Each column represents the mean value of three cell cultures, and the positive error bar represents the standard deviation. An asterisk means that the difference between any two values is statistically significant $(p<0.05)$.

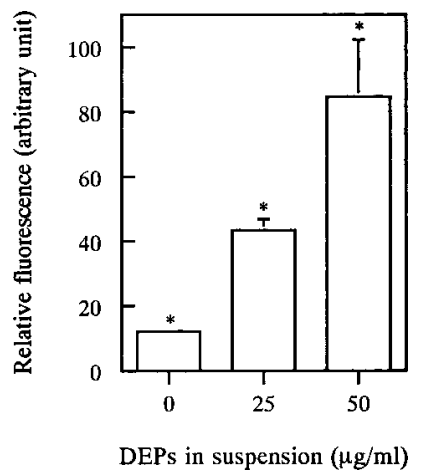

Fig. 4. Quantification of Nitrogen Monoxide Generated within Diesel Exhaust Particle-Exposed Normal Human Bronchial Epithelial Cells

Cells were incubated with $5 \mu \mathrm{M}$ DAF-2 DA in Earle's solution at $37^{\circ} \mathrm{C}$ for $30 \mathrm{~min}$ and then exposed to DEPs at different concentrations at $37^{\circ} \mathrm{C}$ for $1 \mathrm{~h}$. The fluorescence intensity of NO-reacted DAF-2 DA was analyzed by flow cytometry (see Materials and Methods). Each column represents the mean value of three cell cultures, and the positive error bar represents the standard deviation. An asterisk means that the difference between any two values is statistically significant $(p<0.05)$.

with the fluorescence probe DAF-2 DA and then exposed to DEPs, cells emitted green fluorescence under blue illumination (data not shown). The fluorescence shows that nitrogen monoxide is generated within cells. Flow cytometry revealed that DEPs increased the intensity of DAF-2 DA fluorescence

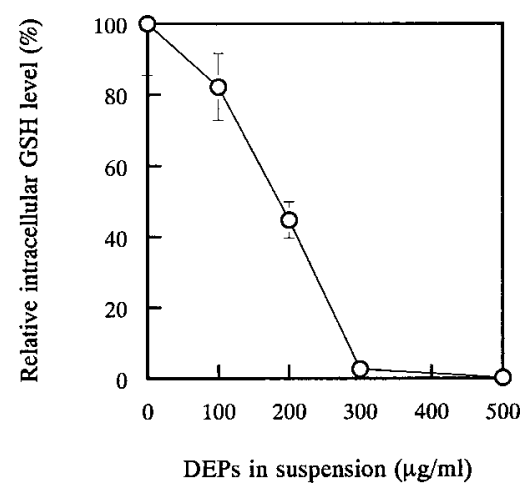

Fig. 5. Relative Reduced Glutathione Level in Normal Human Bronchial Epithelial Cells Exposed to Diesel Exhaust Particles

Cells were incubated with DEPs at different concentrations at $37^{\circ} \mathrm{C}$ for $1 \mathrm{~h}$. Each symbol represents a mean value of three cell cultures, and the positive error bar represents the standard deviation.

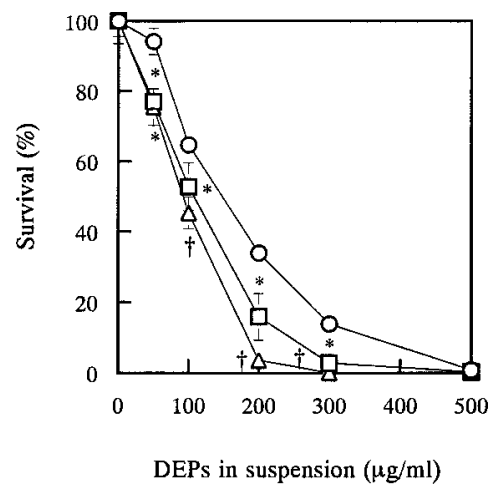

Fig. 6. Survival Curves of L-Buthionine- $(R, S)$-sulfoximine-Preincubated Normal Human Bronchial Epithelial Cells Exposed to Diesel Exhaust Particles

Cells were preincubated with BSO at $37^{\circ} \mathrm{C}$ for $24 \mathrm{~h}$ and then exposed at $37^{\circ} \mathrm{C}$ for $1 \mathrm{~h}$ to DEPs at different concentrations in Earle's solution. Circles, squares, and triangles show the percent survivals of the control, $10 \mu \mathrm{M}$ BSO-preincubated, and $20 \mu \mathrm{M}$ BSOpreincubated cells, respectively. Each symbol represents the mean value of three cell cultures, and the positive error bar represents the standard deviation. An asterisk means that the difference between a value of the BSO-preincubated cells and the corresponding value of the control cells is statistically significant $(p<0.05)$. A cross means that the difference between a value of the $20 \mu \mathrm{M}$ BSO-preincubated cells and the corresponding value of the control or $10 \mu \mathrm{M}$ BSO-preincubated cells is statistically significant $(p<0.05)$.

within cells in a dose-dependent manner (Fig. 4).

Diesel Exhaust Particle Exposure Decreases the Level of Reduced Glutathione in Normal Human Bronchial Epithelial Cells When NHBE cells were exposed to DEPs, their GSH level was sharply decreased in a dose-dependent manner (Fig. 5). Upon exposure to 200 or $300 \mu \mathrm{g} / \mathrm{ml}$ DEPs, the level decreased by 55.2 or $97.3 \%$, respectively. This means that in NHBE cells exposed to more than $300 \mu \mathrm{g} / \mathrm{ml}$ DEPs, their cellular GSH is depleted almost throughout.

Diesel Exhaust Particle Cytotoxicity toward Normal Human Bronchial Epithelial Cells Is Inversely Correlated with the Intracellular Level of Reduced Glutathione Effect of BSO on DEP Cytotoxicity: When cells were preincubated with BSO for $24 \mathrm{~h}$, DEP cytotoxicity increased considerably; the $\mathrm{LC}_{50}$ for 10 or $20 \mu \mathrm{M}$ BSO-preincubated cells decreased by 27.0 or $37.8 \%$, respectively (Fig. 6). Inclusion of BSO in culture media decreased the cellular level of GSH in a dose-dependent manner (Fig. 7). For example, upon preincubation of cells with $25 \mu \mathrm{m}$ BSO for $24 \mathrm{~h}$, their intracellular 


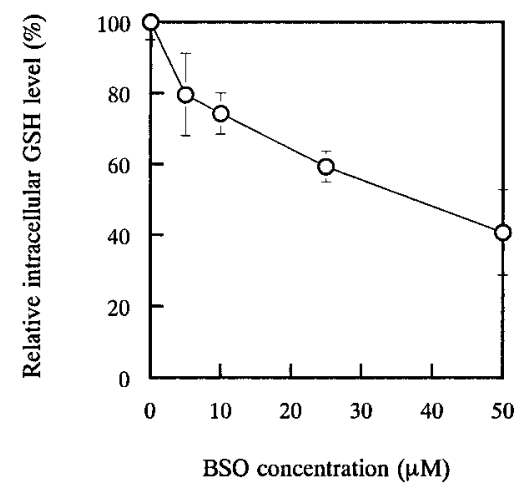

Fig. 7. Relative Reduced Glutathione Level in L-Buthionine-( $R, S)$-sulfoximine-Incubated Normal Human Bronchial Epithelial Cells

Cells were incubated with BSO at different concentrations at $37^{\circ} \mathrm{C}$ for $24 \mathrm{~h}$. Each symbol represents the mean value of three cell cultures, and the positive error bar represents the standard deviation.

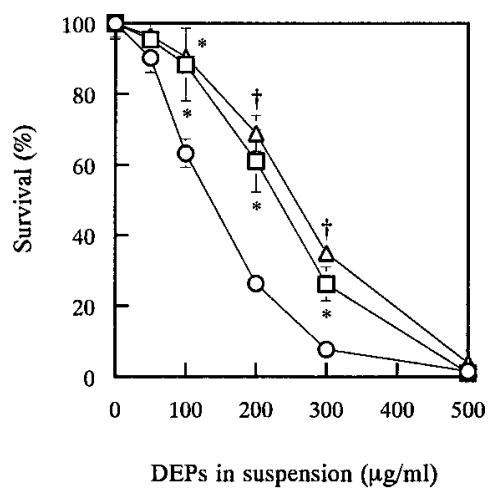

Fig. 8. Survival Curves of Ethyl Reduced Glutathionate-Preincubated Normal Human Bronchial Epithelial Cells Exposed to Diesel Exhaust Particles

Cells were preincubated with EGSH at $37^{\circ} \mathrm{C}$ for $4 \mathrm{~h}$ and then exposed at $37^{\circ} \mathrm{C}$ for $1 \mathrm{~h}$ to DEPs at different concentrations in Earle's solution. Circles, squares, and triangles show the percent survivals of the control, $5 \mathrm{~mm}$ EGSH-preincubated, and $10 \mathrm{~mm}$ EGSH-preincubated cells, respectively. Each symbol represents the mean value of three cell cultures, and the positive error bar represents the standard deviation. An asterisk means that the difference between a value of the EGSH-preincubated cells and the corresponding value of the control cells is statistically significant $(p<0.05)$. A cross means that the difference between a value of the $10 \mathrm{~mm}$ EGSH-preincubated cells and the corresponding value of the control or $5 \mathrm{~mm}$ EGSH-preincubated cells is statistically significant $(p<0.05)$

concentration of GSH decreased by $40.7 \%$.

Effect of EGSH on DEP Cytotoxicity: When cells were preincubated with EGSH for $4 \mathrm{~h}$, DEP cytotoxicity decreased significantly; the $\mathrm{LC}_{50}$ for 5 or $10 \mathrm{~mm}$ EGSH-preincubated cells increased by 69.3 or $87.6 \%$, respectively (Fig. 8). Inclusion of EGSH in culture media increased the cellular level of GSH in a dose-dependent manner (Fig. 9). For example, upon preincubation of cells with $10 \mathrm{~mm}$ EGSH for $4 \mathrm{~h}$, their intracellular level of GSH increased by $55.0 \%$.

Effect of Antioxidants and an Antioxidant Enzyme Mimic on Diesel Exhaust Particle Cytotoxicity PMC, an $\alpha$-tocopherol model compound, decreased DEP cytotoxicity; the $\mathrm{LC}_{50}$ for $100 \mu \mathrm{M}$ PMC-preincubated cells increased by $59.3 \%$ (Fig. 10). Ebselen, a glutathione peroxidase mimic, also decreased DEP cytotoxicity; the $\mathrm{LC}_{50}$ for $1 \mu \mathrm{M}$ ebselencoincubated cells increased by $35.6 \%$ (Fig. 11). However, $\alpha$ tocopherol itself, GSH, and $N$-acetyl-L-cysteine had no effect on DEP cytotoxicity (data not shown). EUK-8, an SOD/catalase mimic, decreased DEP cytotoxicity; the $\mathrm{LC}_{50}$ for $1 \mu \mathrm{M}$

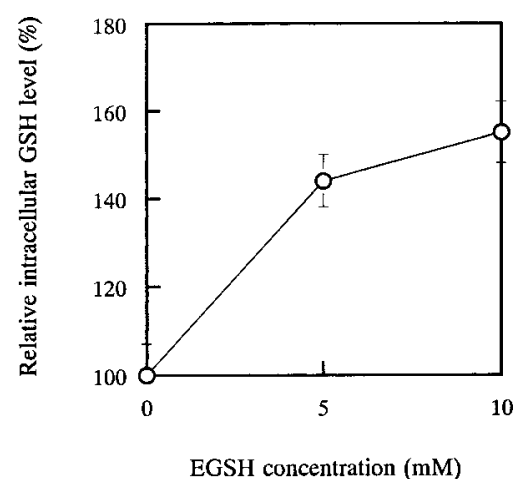

Fig. 9. Relative Reduced Glutathione Level in Ethyl Reduced Glutathionate-Incubated Normal Human Bronchial Epithelial Cells

Cells were incubated with 5 or $10 \mathrm{~mm}$ EGSH at $37^{\circ} \mathrm{C}$ for $4 \mathrm{~h}$. Each symbol represents the mean value of three cell cultures, and the positive error bar represents the standard deviation.

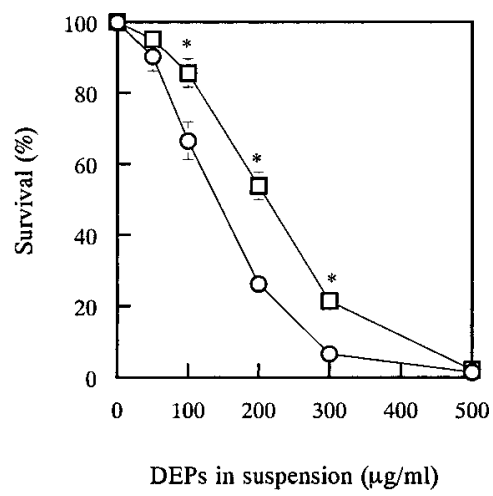

Fig. 10. Survival Curve of $\alpha$-Tocopherol Model Compound-Preincubated Normal Human Bronchial Epithelial Cells Exposed to Diesel Exhaust Particles

Cells were preincubated with $100 \mu \mathrm{M}$ PMC at $37^{\circ} \mathrm{C}$ for $24 \mathrm{~h}$ and then exposed to DEPs at different concentrations at $37^{\circ} \mathrm{C}$ for $1 \mathrm{~h}$. Circles and squares show the percent survivals of the control and $100 \mu \mathrm{M}$-PMC-preincubated cells, respectively. Each symbol represents the mean value of three cell cultures, and the positive error bar represents the standard deviation. An asterisk means that the difference between a value of the PMCpreincubated cells and the corresponding value of the control cells is statistically significant $(p<0.05)$.

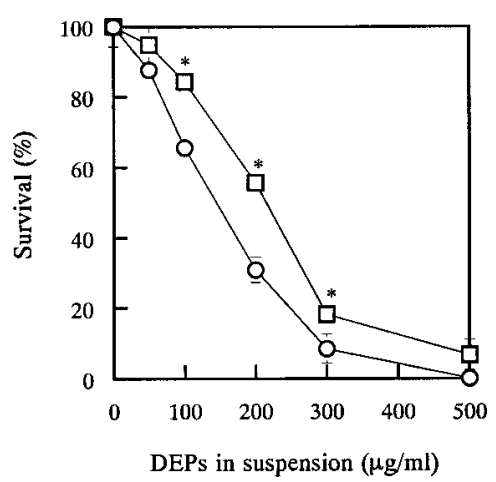

Fig. 11. Survival Curve of Human Bronchial Epithelial Cells Coincubated with Ebselen and Diesel Exhaust Particles

Cells were coincubated with $1 \mu \mathrm{m}$ ebselen and DEPs at different concentrations at $37^{\circ} \mathrm{C}$ for $1 \mathrm{~h}$. Circles and squares show the percent survivals of the control and ebselenincubated cells, respectively. Each symbol represents the mean value of three cell cultures, and the positive error bar represents the standard deviation. An asterisk means that the difference between a value of the ebselen-incubated cells and the corresponding value of the control cells is statistically significant $(p<0.05)$. 


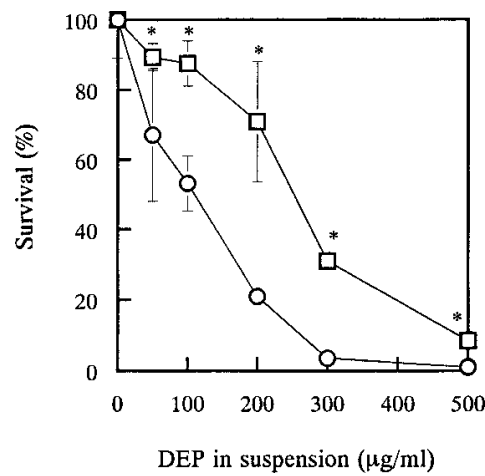

Fig. 12. Survival Curve of EUK-8-Preincubated Human Bronchial Epithelial Cells Exposed to Diesel Exhaust Particles

Cells were preincubated with $150 \mu \mathrm{M}$ EUK- 8 at $37^{\circ} \mathrm{C}$ for $1 \mathrm{~h}$ and then exposed to DEPs at different concentrations in Earle's solution at $37^{\circ} \mathrm{C}$ for $1 \mathrm{~h}$. Circles and squares show the percent survivals of the control and EUK-8-preincubated cells, respectively. Each symbol represents the mean value of three cell cultures, and the positive error bar represents the standard deviation. An asterisk means that the difference between a value of the EUK-8-preincubated cells and the corresponding value of the control cells is statistically significant $(p<0.05)$

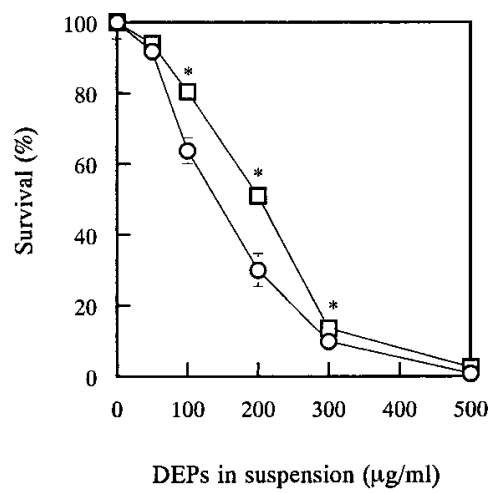

Fig. 13. Survival Curve of $N^{\mathrm{G}}$-Nitro-L-arginine Methyl Ester Hydrochloride-Preincubated Human Bronchial Epithelial Cells Exposed to Diesel Exhaust Particles

Cells were preincubated with $0.3 \mathrm{~mm}$ N-NAME at $37^{\circ} \mathrm{C}$ for $24 \mathrm{~h}$ and then exposed to DEPs at different concentrations in Earle's solution at $37^{\circ} \mathrm{C}$ for $1 \mathrm{~h}$. Circles and squares show the percent survivals of the control and $0.3 \mathrm{~mm}$ N-NAME-preincubated cells, respectively. Each symbol represents the mean value of three cell cultures, and the positive error bar represents the standard deviation. An asterisk means that the difference between a value of the N-NAME-preincubated cells and the corresponding value of the control cells is statistically significant $(p<0.05)$

EUK-8-preincubated cells increased by $129 \%$ (Fig. 12). However, SOD, catalase, and their mixture had no effect on DEP cytotoxicity (data not shown).

Effect of Nitrogen Monoxide Synthase Inhibitors on Diesel Exhaust Particle Cytotoxicity Both L-NAME and L-NMA, which are nitrogen monoxide synthase inhibitors, decreased DEP cytotoxicity; the $\mathrm{LC}_{50}$ values for $0.3 \mathrm{~mm} \mathrm{~L}$ NAME and L-NMA-preincubated cells increased by 45.7 and $53.1 \%$, respectively (Figs. 13 and 14 ).

Effect of Iron Ion-chelating Agents on Diesel Exhaust Particle Cytotoxicity When preincubated in the dark for $24 \mathrm{~h}$ with desferrioxamine mesylate, an efficient chelator of iron(III) ions, or bathophenanthrolinedisulfonate, a chelator of iron(II) and copper(I) ions, DEPs became less cytotoxic. A mixture of $1 \mathrm{mg} / \mathrm{ml} \mathrm{DEPs}$ and $2 \mathrm{~mm}$ desferrioxamine mesylate or bathophenanthrolinedisulfonate was sonicated in Earle's solution containing $0.0025 \%$ Tween 80 , allowed to stand in the dark for $24 \mathrm{~h}$, and diluted with Earle's solution to ap-

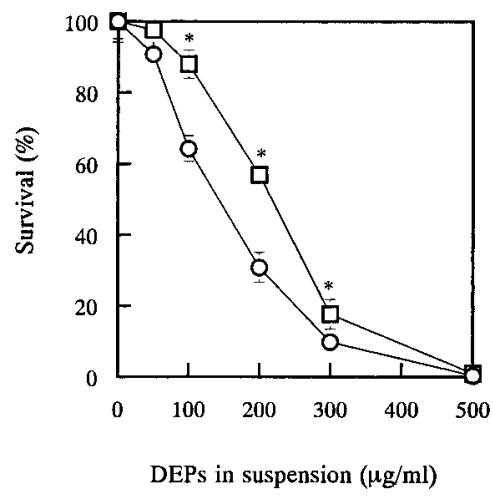

Fig. 14. Survival Curve of $N^{\mathrm{G}}$-Methyl-L-arginine Acetate Salt-Preincubated Human Bronchial Epithelial Cells Exposed to Diesel Exhaust Particles

Cells were preincubated with $0.3 \mathrm{~mm} \mathrm{~N}-\mathrm{NMA}$ at $37^{\circ} \mathrm{C}$ for $24 \mathrm{~h}$ and then exposed to DEPs at different concentrations in Earle's solution at $37^{\circ} \mathrm{C}$ for $1 \mathrm{~h}$. Circles and squares show the percent survivals of the control and $0.3 \mathrm{~mm}$ N-NMA-preincubated cells, respectively. Each symbol represents the mean value of three cell cultures, and the positive error bar represents the standard deviation. An asterisk means that the difference between a value of the N-NMA-preincubated cells and the corresponding value of the control cells is statistically significant $(p<0.05)$.

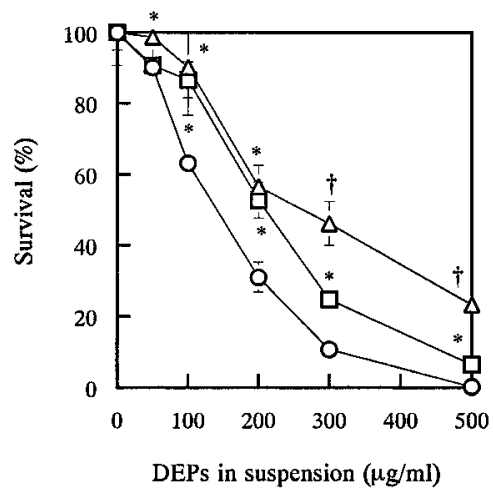

Fig. 15. Survival Curves of Human Bronchial Epithelial Cells Exposed to Diesel Exhaust Particles Preincubated with Desferrioxamine Mesylate or Disodium Bathophenanthrolinedisulfonate

DEPs at $1 \mathrm{mg} / \mathrm{ml}$ were preincubated with $2 \mathrm{~mm}$ desferrioxamine mesylate or disodium bathophenanthrolinedisulfonate in Earle's solution in the dark at $37^{\circ} \mathrm{C}$ for $24 \mathrm{~h}$ and then diluted with Earle's solution to appropriate concentrations. Cells were incubated with the DEPs at $37^{\circ} \mathrm{C}$ for $1 \mathrm{~h}$. Control cells were incubated with untreated DEPs at $37^{\circ} \mathrm{C}$ for $1 \mathrm{~h}$. Circles, squares, and triangles show the percent survivals of cells exposed to DEPs untreated, preincubated with disodium bathophenanthrolinedisulfonate, or preincubated with desferrioxamine mesylate, respectively. Each symbol represents the mean value of three cell cultures, and the positive error bar represents the standard deviation. An asterisk means that the difference between a value of the desferrioxamine mesylate- or bathophenanthrolinedisulfonate-preincubated cells and the corresponding value of the control cells is statistically significant $(p<0.05)$. A cross means that the difference between a value of the desferrioxamine mesylate-preincubated cells and the corresponding value of the control or bathophenanthrolinedisulfonate-preincubataed cells is statistically significant $(p<0.05)$.

propriate concentrations. When cells were incubated in each of the mixtures for $1 \mathrm{~h}$, the $\mathrm{LC}_{50}$ of DEPs increased by $87.9 \%$ for desferrioxamine mesylate and by $48.6 \%$ for bathophenanthrolinedisulfonate (Fig. 15). When the DEPs and each chelator were administered to cells immediately after being mixed by sonication, these chelators had no effect on DEP cytotoxicity (data not shown).

Effect of an Endocytosis Inhibitor on Diesel Exhaust Particle Cytotoxicity Quinacrine, an endocytosis inhibitor, decreased DEP cytotoxicity in a dose-dependent manner (Fig. 16). When cells were preincubated with 0.2 or $0.4 \mathrm{~mm}$ quinacrine for $15 \mathrm{~min}$, the $\mathrm{LC}_{50}$ of DEPs increased by 22.8 or $42.1 \%$, respectively. 


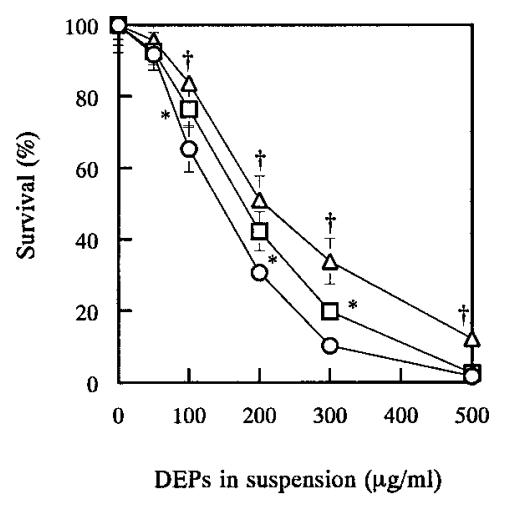

Fig. 16. Survival Curve of Quinacrine-Preincubated Human Bronchial Epithelial Cells Exposed to Diesel Exhaust Particles

Cells were preincubated with 0.2 or $0.4 \mathrm{~mm}$ quinacrine at $37^{\circ} \mathrm{C}$ for $15 \mathrm{~min}$ and then exposed to DEPs at different concentrations at $37^{\circ} \mathrm{C}$ for $1 \mathrm{~h}$. Circles, squares, and triangles show the percent survivals of the control, $0.2 \mathrm{~mm}$ quinacrine-preincubated, and $0.4 \mathrm{~mm}$ quinacrine-preincubated cells, respectively. Each symbol represents the mean value of three cell cultures, and the positive error bar represents the standard deviation. An asterisk means that the difference between a value of the quinacrine-preincubated cells and the corresponding value of the control cells is statistically significant $(p<0.05)$. A cross means that the difference between a value of the $0.4 \mathrm{~mm}$ quinacrinepreincubated cells and the corresponding value of the control or $0.2 \mathrm{~mm}$ quinacrinepreincubated cells is statistically significant $(p<0.05)$.

\section{DISCUSSION}

Figure 1 shows that inclusion of DEPs in culture media is lethal to NHBE cells. Figure 2 shows that when the cells were exposed to 25 or $100 \mu \mathrm{g} / \mathrm{ml}$ DEPs, almost no population of annexin V-FITC-stained, PI-unstained cells was observed, which had phosphatidylserine distributed in the surface of plasma membranes as an early apoptotic event. In DEP-exposed NHBE cells, there was almost no hypodiploid DNA in the PI-stained cells and no increase in caspase 3 activity (data not shown). These results show that DEP exposure leads mainly to necrosis, not apoptosis. Therefore, DEPs may be extremely dangerous to the pulmonary epthelium, because bronchial epithelial cells damaged by DEPs cannot be removed by apoptotic mechanisms. Since DEP exposure to alveolar macrophages and macrophage cell lines has been found to lead to apoptosis, ${ }^{11)}$ the mode of cell death due to DEPs appears to differ depending on cell type.

As shown in Fig. 1, most cytotoxic materials in DEPs cannot be extracted with organic solvents. In the previous paper, we reported that both DEPs and organic solvent-washed residual DEPs were cytotoxic toward HL-60 cells but DEP extracts were not as cytotoxic. ${ }^{9)}$ On the other hand, it has been reported that DEP extracts were cytotoxic toward human pulmonary artery endothelial cells ${ }^{10)}$ and macrophage cell lines. ${ }^{11)}$ The discrepancy in the effects of DEP extracts on cells might result from differences in cell type.

To determine how susceptible NHBE cells are to DEPs in comparison with other normal human lung cell types, we measured the $\mathrm{LC}_{50}$ values of DEPs for NHBE cells, NHPAE cells, and TIG cells, all normal human lung cells. Table 1 shows that NHBE cells are more susceptible to DEPs than NHPAE cells and TIG cells. This also suggests that DEPs may be dangerous to the pulmonary epthelium.

When preincubated with the fluorescence probe DF and then exposed to DEPs, NHBE cells emit green fluorescence under blue illumination, indicating that ROS are generated within the cells. It has been found that in HL-60 cells, ${ }^{9)}$
NHPAE cells, ${ }^{10)}$ and RAW 264.7 cells, ${ }^{11)}$ DEPs induce an increase in the intracellular levels of ROS. DEPs induce an increase in the intracellular level of ROS regardless of cell type. It has already been suggested that in cells exposed to DEPs, ROS, such as the superoxide radical and hydrogen peroxide, are generated nonezymatically by autoxidation of DEP-containing substances like quinones and enzymatically by activation of NADPH cytochrome P-450 reductase. ${ }^{8,10)}$

DEP cytotoxicity correlates inversely with the level of intracellular GSH that has been attenuated with BSO and EGSH. BSO is an inhibitor of $\gamma$-glutamylcysteine synthetase, which catalyzes the biosynthesis of $\gamma$-glutamylcysteine, a GSH precursor. ${ }^{19)}$ Inclusion of BSO in culture media decreases the level of intracellular GSH (Fig. 7). EGSH is a GSH carrier across cell membranes. ${ }^{19)}$ Inclusion of EGSH increases the level of intracellular GSH (Fig. 9). Further, DEPs themselves sharply decrease the level of intracellular GSH in a dose-dependent manner (Fig. 5). When NHBE cells are exposed to DEPs at a high concentration of more than $300 \mu \mathrm{m} / \mathrm{ml}$, their intracellular GSH is depleted almost throughout. Figure 1 shows that under these conditions, the cells can no longer survive. We have already observed an inverse relationship between DEP cytotoxicity and the level of intracellular GSH in HL-60 cells. ${ }^{9)}$ In a variety of cell types, GSH may act as the first line of cellular antioxidant defense to scavenge DEP-induced ROS.

Preincubated PMC, an $\alpha$-tocopherol model compound, suppressed DEP cytotoxicity toward NHBE cells (Fig. 10), although $\alpha$-tocopherol itself had no effect (data not shown). A difference between the suppressive effects of $\alpha$-tocopherol and its model compound has also been found in HL-60 cells. ${ }^{9)}$ Since $\alpha$-tocopherol and the model compound are fatsoluble antioxidants, these compounds can be incorporated into cells. It is presumed, however, that the former may be mostly trapped in cell membranes due to its long isoprenoid side chain and that the latter may reach the cytosol. This might be the reason why their effects on DEP cytotoxicity differ.

As shown in Fig. 11, ebselen suppresses DEP cytotoxicity. Ebselen is a glutathione peroxidase mimic. Thus, it scavenges ROS, presumably hydrogen peroxide, to protect cells from DEP cytotoxicity. On the other hand, the water-soluble antioxidants $N$-acetyl-L-cysteine and GSH had no effect (data not shown). They may be ineffective due to its low lipophilicity. Inclusion of SOD and/or catalase in culture media had no effect (data not shown). However, EUK-8, an SOD/catalase mimic, decreased DEP cytotoxicity (Fig. 12). This result may be explainable on the basis of the cell membrane impermeability of SOD and catalase.

After 24-h preincubation with desferrioxamine mesylate, an efficient chelator of iron(III) ions, or bathophenanthrolinedisulfonate, a chelator of iron(II) ions and copper(I) ions, DPEs became less cytotoxic (Fig. 15). This shows that iron ions play important roles in DEP cytotoxicity. Presumably, hydrogen peroxide is produced in the presence of DEPs and converted to the hydroxyl radical by the Fenton mechanism in the presence of iron(II) ions, which have been produced from reduction of iron(III) ions with the superoxide radical. The hydroxyl radical acts as a highly cytotoxic agent. When DEPs and each chelator were mixed and immediately administered to cells, however, the DEPs remained highly cyto- 
toxic. Within a short period of incubation time, these chelators may be unable to reach iron ions within DEPs and to mask iron ions.

It has been observed that in NHPAE cells, DEPs stimulate nitrogen monoxide synthase to increase the level of NO production. ${ }^{10)}$ Figure 4 suggests that in NHBE cells, DEPs also stimulate nitrogen monoxide synthase to increase the level of NO production. DEPs stimulate the producton of NO, which may be converted to peroxynitrite in the presence of the superoxide radical, and then the peroxynitrite may react with hydrogen peroxide to give the hydroxyl radical.

As mentioned above, ebselen suppresses DEP cytotoxicity. It has been reported that ebselen can act as a peroxynitrite scavenger with the advantage of a high reaction rate. ${ }^{20,21)}$ Thus, the ebselen-induced decrease in DEP cytotoxicity might mean that it not only scavenges hydrogen peroxide but also scavenges peroxynitrite.

DEP cytotoxicity toward NHBE cells decreased in the presence of quinacrine (Fig. 16), an endocytosis inhibitor. ${ }^{22)}$ It has been found that DEP cytotoxicity toward HL-60 cells decreased in the presence of quinacrine, ${ }^{9)}$ and in addition that RAW264.7 and THP-1 cells phagocytosed DEPs. ${ }^{11)}$ These observations show that DEPs are easily incorporated into cells by endocytosis and/or phagocytosis.

In summary, NHBE cells engulf DEPs by endocytosis. The engulfed DEPs decrease the intracellular GSH level and generate the superoxide radical, hydrogen peroxide, and nitrogen monoxide enzymatically and/or nonenzymatically. In the presence of iron(II) ions, the hydrogen peroxide is converted to the hydroxyl radical, and in the presence of the superoxide radical, the NO is converted to peroxynitrite, which reacts with hydrogen peroxide to give the hydroxyl radical. The hydroxyl radical and peroxynitrite damage biomolecules destructively, leading to necrosis. Thus, DEPs injure NHBE cells irreversibly, triggering severe pulmonary damage. Presumably, DEPs act as a very dangerous agent to respiratory organs.

\section{REFERENCES}

1) Dockery D. W., Brunekreef B., Am. J. Respir. Crit. Care Med., 154, S250-256 (1996).

2) Schwartz J., Environ. Res., 62, 7-13 (1993).

3) Xu X., Wang L., Am. Rev. Respir. Dis., 148, 1516-1522 (1993).

4) Ichinose T., Yajima Y., Nagashima M., Takenoshita S., Nagamachi Y., Sagai M., Carcinogenesis, 18, 185-192 (1997).

5) Sagai M., Furuyama A., Ichinose T., Free Radic. Biol. Med., 21, 199209 (1996).

6) Sagai M., Saito H., Ichinose T., Kodama M., Mori Y., Free Radic. Biol. Med., 14, 37-47 (1993).

7) Vogl G., Elstner E. F., Toxicol. Lett., 47, 17-23 (1989).

8) Lim H. B., Ichinose T., Miyabara Y., Tanaka H., Kumagai Y., Shimojyo N., Devalia J. L., Sagai M., Free Radic. Biol. Med., 25, 635-644 (1998).

9) Matsuo M., Uenishi R., Shimada T., Yamanaka S., Yabuki M., Utsumi K., Sagai M., Biol. Pharm. Bull., 24, 357-363 (2001).

10) Bai Y., Araki K., Sagai M., Free Radic. Biol. Med., 30, 555-562 (2001).

11) Hiura T. S., Kaszubowoski M. P., Ning L., Nel A. E., J. Immunol., 163, 5582-5591 (1999)

12) Bayram H., Devalia J. L., Sapsford R. J., Ohtoshi T., Miyabara Y., Sagai M., Davies R. J., Am. J. Respir. Cell. Mol. Biol., 18, 441- 448 (1998).

13) Kaneko T., Nakano S., Matsuo M., Lipids, 26, 345-348 (1991).

14) Ohashi M., Aizawa S., Ooka H., Ohsawa T., Kaji K., Kondo H., Kobayashi T., Noumura T., Matsuo M., Mitsui Y., Murota S., Yamamoto K., Ito H., Shimada H., Utakoji T., Exp. Gerontol., 15, 121133 (1980).

15) Yamamoto K., Kaji K., Kondo H., Matsuo M., Shibata Y., Tasaki Y., Utakoji T., Ooka H., Exp. Gerontol., 26, 525-540 (1991).

16) McAteer J. A., Davis J. M., "Basic Cell Culture, A Practical Approach,” ed. by Davis J. M., IRL Press at Oxford University Press, New York, 1994, pp. 93-148.

17) Peterson G., Methods Enzymol., 91, 95-119 (1983).

18) Griffith O. W., Anal. Biochem., 106, 207-212 (1980).

19) Honda S., Matsuo M., Biochem. Internatl., 26, 525-540 (1991).

20) Matsumoto H., Sies H., Chem. Res. Toxicol., 9, 262-267 (1996).

21) Squadrito G. L., Pryor W. A., Free Radic. Biol. Med., 25, 392-403 (1998).

22) Mayorga L. S., Colombo M. I., Lennartz M., Brown E. J., Rahman K. H., Weiss R., Lennon P. J., Stahl P. D., Proc. Natl. Acad. Sci. U.S.A., 90, 10255-10259 (1993). 